\title{
The Dual Attitude towards the Arab Personality in the Contemporary Hebrew Children's Literature: A Critical Analysis of Ronette Gettleman's 'On Her Way'
}

Mohammad Al- Nusirat*, Mahmoud Al-amrat, Taisaer Al-azzam

Department of Semitic and Oriental Languages, Yarmouk University, Jordan

Received on: 18-2-2020

Accepted on: 28-7-2020

\begin{abstract}
Having received a noticeable stature in the contemporary Hebrew children's literature, Ronette Gettleman is one of the most renowned authors who have addressed the issue of hate speech and the culture of peace in contemporary Hebrew children's literature. Hate speech is considered part of Zionist literature. Gettleman's story On Her Way is a prominent piece of prose that depicts the Arabs and their image in Israeli children's minds. Hence, the story On Her Way was chosen as an attempt to identify, through selected excerpts from the story, how the Arab person is negatively portrayed in contemporary Hebrew children's literature. The author, through some Israeli children, expresses the concepts of hostility and hatred in their conscience towards the Arab character. Like other Israeli authors, Gettleman shows that the image of Arabs in Hebrew literature raises fear, anxiety and terror whenever Israeli children hear the word "Arab". It also makes the culture of hatred and hostility a headline for the Israeli child. In contrast, the author highlights the culture of coexistence and peace among some Israeli children towards the Arab character. The story demonstrates that there are some Israeli children who are willing to coexist and live peacefully with Arabs. This story with its focus on both hatred and hostility on the one hand and coexistence and peace, on the other, shows the dual attitude of Israeli children towards Arabs. This is a new trend in contemporary Hebrew children's literature towards the Arab character and its positive outlook.
\end{abstract}

Keywords: Contemporary Hebrew Children's Literature, Hate speech, Culture of peace, Ronette Gettleman, On Her Way.

\section{Introduction}

In any culture of the world and the Hebrew one as an example, children's literature is an educational instrument that enhances certain values such as morality, religion and nationalism (Jubah, 2005: 47; Rosenthal, 2005: 7). It has a clear-cut impact on children as many socio-political concepts can be so enriched and transferred from one generation to another. The words in this literary genre are more than being forms for ideologies or common expressions to affect a child's emotions (Cohen, 1998: 9). The children's literature in Hebrew has not been generally written as per artistic or literary criteria as it is the case in the other nations of the world. It has been actually written to express a Zionist ideology for a generation to believe in its values, thoughts and teachings (Jubah, 2005: 47).

\footnotetext{
๑ 2021 JJMLL Publishers/Yarmouk University. All Rights Reserved,

${ }^{*}$ Doi: https://doi.org/ 10.47012/jjmll.13.2.4

* Corresponding Author: mnusirat@yu.edu.jo
} 
The contemporary Hebrew children's literature $(C H C L)$ has become today an integral component of the Zionist culture. Since declared in 1948, the state of Israel has been emphasizing this literary genre by means of education and literature. Both Israeli authors and educationists have paid a lot of attention to this genre (Sabri, 1997: 25). Suiting little age groups, the child-oriented story has thus had its own artistic structure to consist of well-devised applications aiming at deforming the Arab image in the mind of an Israeli child (Qarnia, 2011: 261; Abdul-Aal, 2005: 25). The stereotype depicted for the Arab personality in Israel is very negative and malformed (Qarnia, 2011: 291), the matter which the Israeli writer, politician and critic Uri Avnery ${ }^{1}$ so confirms:

"[I]f you, citizen of Israel, want to have at your own house a little Nazist, you just need to go to the children's library and buy a book of Geulah Cohen²depicting the Arabs as terrorists and murderers who kidnap children, rape women... and are only seeking to eliminate us and deprive us of our historical rights on our ancestors' land" (1981: 30).

Several studies on the contemporary Hebrew literature have addressed the deformed Arab image as perceived by the Israeli children. Among them are the following four ones on two levels:

1. The first one could be considered as the initial, anxious level of the hate speech in the CHCL. As one of the earliest studies published in Arabic, Ghanim (1986) examined the Arab personality in the modern Hebrew literature through a set of translated extracts. He addressed the negative features of this personality from a Zionist perspective. In the same spirit, a study entitled as 'Ugly Faces in the Mirror' by Adir (1988) tackled the reflections of the Arab-Israeli struggle on the Hebrew children's literature. As also one of the earliest articles yet in Hebrew, it examined the Arab image and how the Israeli children began to be racially and politically educated about the deformed Arab personality.

2. The other level, however, was more or less settled; the Israeli themes of hatred and hostility toward the Arab personality were set to more maturity. A study by Sabri (1992) entitled as 'the ideological attitudes...' investigated the evolution of the CHCL in Israel and what role(s) it played to develop an Israeli's value system as per the Zionistic thought. In another article by Samida (2000), the Palestinian personality in particular was then the one addressed by the Hebrew short story. Explaining the real Arab personality as it had been strategically deformed or, say, eliminated by the Zionist literature, the study attempted to prove false all or any aggressive or criminal characteristics the Arab person has been always accused of.

Shedding light on the speech of hatred and hostility against the Arab personality in Gettleman's On Her Way, the present study is intended to be an addition. Its major novelty in this particular field of research is almost attained by having dealt with a newly published short story (2019) by one of the most renowned CHCL authors in Israel. A various set of extracts of this literary work were chosen as examples to demonstrate the hate speech in the modern literature of Hebrew and how the Israeli children are taught to perceive the same. By way of her characters, Gettleman shows the negative, egotistical and discriminatory view toward to the Arabs. On the other hand, Gettleman expresses in her story how some 
The Dual Attitude towards the Arab Personality in the Contemporary Hebrew Children's Literature: A Critical Analysis of Ronette Gettleman's 'On Her Way'

of her characters support coexistence and living peacefully through having positive attitudes towards Arabs. This positive attitude towards coexistence and peace is in line with the ones reported in previous studies. For example, in her study on the culture of peace according to Israeli children, Sabri (1999) shows how some Israeli children view the relationship between Arabs and Israelis in lights of real and fair peace.

To observe what is really taking place inside the Israeli society against the Arabs requires a sound, conscious investigation. The Israeli approaches and/or procedures in dealing with their non-Jewish "countrymen" and the most public ideologies outlined by the Israeli authors need to be examined. For this aim, Gettleman's On Her Way was selected as a case for demonstrating the amount of hatred, hostility and melancholy some of Israeli children could keep in their minds toward the Arab personality. At the same time, Gettleman tries to present the positive attitude that some Israel children have towards Arabs. In harmony with this dual attitude towards the Arab personality in contemporary Hebrew children literature, the present study aims at highlighting such kind of culture by answering the following research questions:

1. What is the significance of 'hate speech' in the Israeli educational thought and Hebrew children's literature in deforming the Arab image?

2. How is Ronette Gettleman viewed in the contemporary Hebrew literature? Who is she and what is her story 'On Her Way' about?

3. To what extent could Gettleman address the concepts of hatred and hostility in the mind of an Israeli child toward the Arab personality?

4. How does Ronette Gettleman show trends of coexisence and peace among some Israeli children in the story?

\section{Hate Speech in the Hebrew Children's Literature}

\subsection{Hatred and Zionist Education in Literature}

Different definitions of hate speech have been proposed by many scholars (Cohen-Almagor 2011; Faris et al. 2016; Weidmann 2009). Yet, generally, according to Siegel (2019: 2), hate speech is "understood to be bias-motivated, hostile and malicious language targeted at a person or group because of their actual or perceived innate characteristics." Siegel further (2019: 20) argues that "hate speech may foster an environment in which bias-motivated violence is encouraged either subtly or explicitly [....] intergroup conflict is more likely to occur and spread when individuals and groups have the opportunity to publicly express shared grievances and coordinate collective action." Writing stories, novels and plays is considered as a public way of expressing attitudes, emotions, ideologies and values. Hebrew literature overtime, including Hebrew children's literature, has received great interest in Jewish thought to mirror their attitudes and ideologies in terms of the way of dealing with other nations (Zinberg, 1978).

Prior to the declaration of the state of Israel, Zionism, since organized in 1897, insisted on the educational aspect. ${ }^{3}$ It has believed in a generation to grow up as per its principles and thoughts (Qarania, 
2011: 255; Dar, 2017: 1). As declared in 1948, Israel has started paying much care of its children-oriented literature for developing the Jewish personality (Mezal \& Amro, 1989: 6; Rudin, 2015: 32). A child is certainly a future maker (Qarania, 2011: 277; Rosenthal, 2005: 5) and states man who will be working hard with a great sense of his/her country's interests (Abdul-Aal, 2005: 28; Shavit, 2000: 15). In this spirit, Sabri (1997) argues that the CHCL:

"[d]raws up the policies of racism followed by Israel since established. It is a cultural component that has its own effect on children, who are actually the men and women of the future and decision-makers of the Zionist policies” (p. 22).

The children's literature in Hebrew is different from that in other languages in terms of its trends of thought. It can be really considered as a dangerous device used by the educational system in Israel for politically teaching and directing its children (cf. Shalabi, 1992). Therefore, this literature can be classified as an integral part of the Israeli strategic system not for entertainment (Qarnia, 2011: 280). It is also a Zionist plot to deform the Arab image and strengthen the Israeli children's feelings of hatred and hostility toward the Arab or Palestinian personality (Mezal \& Amro, 1989: 38-39; Cohen, 1988: 5). In the same respect, the Israeli researcher, Menachem Regev stresses that "the most prominent issue the children's literature in Hebrew addresses is the Arab person [...] who appears [to the people of Israel] as a maddening nightmare" (1984: 60).

In addition to their being cruelly ridiculed, the Arabs are deprived of their human characteristics in the CHCL in a prejudicial manner. The literary writings in Hebrew are rich of horror- or struggle-centred themes an Israeli child is unconsciously obliged to accept and follow in any dealing with any Arab person or object. As a core value of the Israeli education, this kind of literature has thus become an organized attempt to deform the Arab image in the minds of children (Sabri, 1997: 10; Suleiman, 2011: 106). What a child also needs to learn is the Arabs are only seeking to clean the Jews out of any region of the world not only Palestine (Mezal \& Amro, 1989: 74-75). They are depicted to be only murderers who have no mercy and need to be brutally fought (Meza 1\& Amro, 1989: 74; Rudin, 2015: 31). According to Adir Cohen a big mistake in the Israeli children's books is that:

"[t]hey focus on the Arabness not the humanity of the Arabs [...]. They often do the same in a radical manner to [only] distort facts. An Arab person is depicted as a weird, primitive being who totally has no knowledge and deserves to be disrespected or refused" (1988: 188).

\subsection{The Arab Personality in the CHCL}

As a considerable literary genre, the short story has its own status in the CHCL. It plays a vital role in emphasizing several Jewish realities (Samida, 1988: 34) and exploring the problems the Jews inside or outside Israel might have been facing (Halkin, 1960: 83). It was relied upon as an artistic device to indirectly transfer thoughts to children because it is written compactly enough to fit a child's mental capacity (Samida, 1984: 67). Traced back to the 1950s, the Arab or Palestinian personality was addressed by a lot of child-oriented literary works in various stages and genres (see also שביט, 2000: 11-18; Sabri, 1997: 25-34; Samida, 2000: 25-59; Messiah,2006: 296-7). It has been the central issue or pivotal concern 
The Dual Attitude towards the Arab Personality in the Contemporary Hebrew Children's Literature: A Critical Analysis of Ronette Gettleman's 'On Her Way'

to the Hebrew authors, the matter which reflects the Israeli or, basically, Zionist racial view toward the Arabs (Mezal, 1986: 38; Rudin,2015: 30).

Most children's short stories addressing the Arab personality in the CHCL are based on such themes as hatred and hostility (Jubah, 2005: 25). In this respect, Gilad Morag, an Israeli critic, stresses that this 'personality' as depicted in the Hebrew literature "still causes fear and anxiety to [both] Israeli children and young people" (Morag, 1987: 17). The following is a set of short stories in Hebrew:

- The Animal of Darkness by Uri Orliv depicts an Arab person as an ugly horrifying being and, in particular, a real menace to the Israeli children (cited in Mezal \& Amro, 1989: 40-41). It is narrated by little age-groups so that it can really create a rift in the Israeli children's mentality, personality and behavior as they deal with or even think of the Arabs.

- An Arab with Mustache by Etgar Keret misrepresents the Arabs, showing the Jewish superiority over them. The author tries to belittle the Arab person's deginity and humanity for strenghtening the Israeli children's hatred and hostility (Keret, 2002: 68-69). Living under this umbrella, an Israeli child cannot feel but that the Arabs deserve no respect (Jubah, 2005: 88-89).

- The Prince and the Moon ${ }^{4}$ by Uri Evans highly misrepresents the Arabs; they are depicted as murderers or thieves who are only seeking to distort the children's sweet dreams (Qarnia, 2011: 286). The "peace-loving" Israeli children are urged to hate the Arabs and inevitably conclude that they must be fought as they steal the moon and kill the innocent youg prince (Suleiman, 2011: 111).

- Niar against Salim by Amnon verner sheds light on the Arab-Jewish relations in Israel, describing the issue of racial discrminitation among the Israeli youngmen. The image created by the author reflects the Israeli ideology of racism, superiority and violence in the Israeli children's minds towards the Arabs in general and Palestinians in particular (Rudin,2015: 49-51).

\section{Ronette Gettleman's Life and Works}

Gettleman is an Israeli author and journalist, born in Israel in 1975. She studied at Ben-Gurion University (The Nuritha Books and Literature website) majoring in Hebrew literature and political science. She has been also known for her calligraphic skills as she is a member and coordinator of the Israeli Graphology Association (Gettleman,2014). Ronette Gettleman is actually considered as one of the most renowned contemporary authors in the Hebrew literature in Israel; she has written several children's short stories and-since children's literature is of a highly important role particularly in the Jewish educational system - received great interest from national critics and writers.

Three famous short-story collections have been written by Ronette Gettleman. The first one was published in 2014 under the name of Delicious Ripe Orange. Narrated by its protagonist Jonathan as he returns back from an orchard and refuses his family's suggestions for how to do with the oranges he picks, the story has an unexpected ending and entails educational messages to children. Written in 2016 and entitled as The Wonderful Journey of Bone the bear, the second collection talks about a bear which finds itself sad and frustrated as all the animals in the jungle are busy with their affairs and have no time to play with it. Bony decides to leave and search for new friends and, finally, feels happy and satisfied. In 
2019, Gettleman published her third short-story collection On Her Way. It reflects the Arab-Jewish relations as well as the Israeli culture of hatred and hostility toward the Arab personality (Lutzsschwily, 2019). In a simple language, Gettleman's stories aim at deepening the Israeli children's feelings and pursuits to explore themselves and the world around (cf. Snir, 2016).

\subsection{On Her Way}

As referred to above, the latest short story by Gettleman was published in 2019 and consists of ten parts. It starts with a conversation about the Arab girl Sherine, the daughter of a family from the Arabs of Palestine. Sherine migrates with her family to the city of Haifa, where her parents leave their village in search of work and instant income. When she arrives in the city, she joins to a Jewish school and-in the beginning of the first day of her study-Sherine enters the school and feels of fear and anxiety yet with some joy and happiness. The author describes the Israeli students' negative view(s) toward this Arab girl; they insist on knowing her origins in spite of her refusal at first to reveal her Arab identity.

In the second part of the story, the author describes the great efforts exerted by Sherine's parents so that she can adapt to the new school in Haifa. As time passes, Sherine starts adapting to the Jewish environment, focusing on her school subjects and participating in non-class activities. Also, she exchanges visits and meetings with her Israeli friends, especially Chirah and Eiden. The author redescribes the problem of the students regarding their view of Sherine and their question: Is she Arab or not? One of the students tells that Sherine comes from a northern Arab village, and the children whisper and laugh again when they see Sherine. The parents are still depicted to support their daughter and her sport talent. She joins a sports club in Haifa and aspires to become a famous athlete. She wins the global competition of gymnastics and receives medals and awards.

For the third part, the story describes how many years pass as Sherine moves to high school along with her Israeli friends Shira and Eiden. The author then goes on to talk about Miss Iris and what she speaks to the students about an operation or explosion that occurs in Tel Aviv after Prime Minister Ariel Sharon's visit to Cairo for renewing the peace negotiations between the two countries. The story describes the negative reaction of the Israeli children to the Arab resistance fighters as some of them reject the idea of peace or any co-existence with the Arabs. Miss Iris returns to talk to the students again about the importance of peace and its positive dimensions to both Jewish and Arab peoples in Palestine. She stresses how the Palestinian people suffer from the Arab-Israeli conflict; however, her views of the same are rejected by some students who themselves reject the culture of peace unless it is devised from an Israeli perspective.

The author moves in the fourth and fifth parts of the story to talk about a dialogue between Sherine and her mother. The author describes the mother's anger at her daughter because she becomes interested in sports more than her studies as sport talents cannot be professions. However, Sherine does not change her mind because her talent is just a life to her; it is her future and the whole world in her eyes. Sherine achieves part of her dream; she wins the second place in the competitions of gymnastics held in Israel for her jumping skills. Sherine feels very happy when she is surprised by the presence of her father and mother in these competitive activities: how they support her, especially her father who is highly proud of 
The Dual Attitude towards the Arab Personality in the Contemporary Hebrew Children's Literature: A Critical Analysis of Ronette Gettleman's 'On Her Way'

her. Also, her mother fortunately changes her mind concerning Sherine's sport talents and becomes proud of her too.

In the sixth part, the author talks about the annual trip made by the Jewish and Arab students to the Judean desert in southern Israel. The idea of coexistence is the one expected to emerge between the students as, at least, they eat food together. However, the culture of hatred and fear of the Arabs reappears in the story again by Jay and Lior who try to caution their friend Chirah from the Arab student Sherine despite the former's attempts to defend her and ignore what the others say or claim. Her insistence on talking about Sherine and the extent to which she feels attached to her as well as the strong friendship that exists between them are things to stress. Chirah actually calls for coexistence and peace, but these concepts were rejected by the other children.

In the seventh part of the story, the author moves on to talk about the mutual emotional relationship between Sherine and the Israeli student Omir. She is depicted to have feelings of something beautiful towards him. In this part, Omir suggests for her to go out with him to have a drink together, called "milk shake", in one of the cafes on an eve celebration of so-called Israel establishment. At first, Sherine actually hesitates and refuses to go out with this new friend, remembering her mother's words and her advice to her not to go for preserving her honour and dignity and respect for the values, customs and traditions of her Arab community. However, at the end, she finds herself willing to break those values and customs by accepting a short leave with the young Israeli Omir.

In the eighth part, the author describes the party held at the school for celebrating the memorial of the so-called victims of the Israeli army as well as the casualties of military operations in the army. Sherine refuses to participate in this celebration; however, she attends that day in exchange for her first romantic meeting that will bring her together with Omir. She actually refuses all the invitations and waives all of her dates in exchange for her meeting with this new friend and classmate. Sherine tries to be hidden from her other friends and not to have this relationship or meeting concealed to any of them. Omir is depicted to be a dream of every teenage girl. Lastly, Sherine goes out with her 'prince' Omir and becomes wandering with him around the city, so her classmate, Eiden, sees her in the city centre.

In the ninth part of the story, the author describes Sherine's return to school after the vacation. Her friend Eiden ignores her and refuses to talk to her while she attempts to find out the reason behind this disregard. Then, a conversation takes place between Sherine and Eiden, and Sherine reveals to her that she fell in love with Omer five months ago. Eiden becomes angry and tells her she is aware of that emotional relation. Sherine tells her that she does not trust her. Nonetheless, Sherine goes on her way and approaches in her life to achieve the dreams she ever wants to come true despite any challenges she may face. Then, the author tells a number of demonstrations and banning marches bearing slogans of death to the Arabs and how Sherine reacts to the same refusing this kind of hatred and hostility.

In the final part, the story ends with the participation of Sherine in the gymnastic competition in the Olympic Games accompanied by her parents and dozens of Israeli athletes. During this journey of Sherine, a party is held at the end of the school year, and the headmaster delivers a speech in front of the students referring to Sherine's sport talents. He wishes her all success, confirming the same by saying: 
"She represents all of us." However, the culture of hostility and hatred returns to the students again, especially Jay who ridiculously says: "She does not represent us; she represents only herself and she will not succeed." In the meantime, it is announced that the Arab-Israeli contestant, Sherine Naim, will win the gymnastic competition in the Olympic championship. Eventually, she is awarded for her supposed-to-be country "Israel" and joy reigns among some students.

\section{Aspects of Hatred and Hostility toward the Arab Personality}

\subsection{Culture of Hostility and Racism and Fear of the Arabs}

As a main phenomenon among the little Jewish children in the state of Israel, the culture of hatred, racism and hostility aims at teaching them how to hate and be afraid of the Arab people (Jubah, 2005: 150; Rudin, 2015: 31). In this respect, Gettleman expressed this kind of culture through her characters, e.g. the Arab girl Sherine as she enters the school and her peer students who insist on recognizing her and knowing her origins. Actually, the students hate her once they know she is Arab. The author says:

"זה היה היום הראשון לשנת הלימודים. אל כיתה ד'1, נכנסה באיחור תלמידה חדשה, קצת מפוחדת, קצת שמחה. עיני כל הילדים נשאו אליה, ובחנו את דמותה... בהפסקה, כשכל הילדים מילאו את החצר, נשארה התלמידה החדשה לשבת בכיסאה בכיתה. ניגשו אליה כמה ילדים וביקשו לדעת מה שמה, מאיין הגיעה... אך הילדה שתקה ולא סיפרה להם דבר... בשיעור האחרון באותו היום פנתה לפתע המחנכת שרית אל התלמידה החדשה בשמה "שירן, ברוכה הבאה אל כיתתנו....לבסוף לחשה שירן בקול שכמעט ואינו נשמע "תודה", אך שרית לא הבינה והוסיפה "את רוצה לספר לנו קצת על עצמך?" שאלה. שוב שתקה....נשמע קול חזק מכיוון אחד השולחנות האחרונים של הכיתה, "היא ערבייה!" קרא מישהו בקול חד, לא ברור מי. דממה שררה בחדר.... הפעם היה תורה של שרית לשתוק, גם היא הביטה בשירן, מנסה לארגן את מחשבותיה בטרם תגיב ואז השתיקה הופרה בלחשושים של התלמידים. "אני חושבת שהיא עולה חדשה," אמרה, שירה שישבה בקדמת הכיתה. "שירן זה לא שם ערבי" פסק ליאור, וילדה אחרת פשוט שאלה אותה "אולי תגידי לנו, את ערביה או לא?" וכך חזר השיח ועלה בקולי קולות" (גיטלמן, 2019: 11-9).

"It was the first day of the year. The new student came late to the class of the fourth grade while she's feeling a little bit of happiness and another bit of fear. All the children's eyes were headed toward her, to check her look and image. At the break, all the students spread on the school yard; only the new one remained sitting on her seat in the classroom. When several kids approached her and asked to know where she comes from and what her name is? But the girl remained silent and she didn't talk back. At the last lesson of that day, Miss Saryet surprised the new student by saying: "Welcome to our classroom, Sherine." Finally, the girl whispered with a nearly unheard voice: "Thanks" so Miss Saryet looked at her again and asked her if it's possible for her to introduce herself a little but [Sherine] once again didn't answer. A loud voice was heard from one of the last tables in the classroom as an unknown person said 
The Dual Attitude towards the Arab Personality in the Contemporary Hebrew Children's Literature: A Critical Analysis of Ronette Gettleman's 'On Her Way'

out loudly: "Sherine is Arab!" Silence prevailed in the classroom and, in this time, Miss Saryet kept silent. She looked at Sherine and she tried to organize her thoughts and responses. The silence was accompanied by mutual whispers among the students. Chirah who was sitting in the front seat said: "I think she is a new immigrant." Lior said: "Sherine is not an Arabic name." Another girl simply asked her: "Maybe you tell us: Are you Arab or not?" And so the conversation began to rise loudly." 5

The paragraph above refers to the Israel children's negative reaction and racial attitude toward Sherine. It depicts the extent to which they are afraid or feel of anxiety as they see this Arab girl. Overlapping with the 'fear-of-the-others' (or social phobia) notion devised by the Israel sociologist Mosheh Tsukerman, this kind of fear is a component of the present Israeli personality. A citizen of Israel needs to be always ready for any of who might cause damage to his/her nation, the matter which entails that no Jewish person deserves his/her trust (Abu Ghadeer, 2008: 36). In another scene of her story, the author also describes the children's racial attitudes toward the Arab personality as they ignore or refuse the Arab girl Sherine to be a student of their school. She says:

"מישהו מהתלמידים דיווח ששירן נראתה בחדר המחשבים מול המסך בו הוצגו תכנים בשפה הערבית, ותלמיד נוסף סיפר ששירן הגיעה מכפר ערבי בצפון הארץ...בכל פעם ששירן הופיעה אל מול עיני הילדים, הם היו מתלחששים ומצחקקים. חלקם התעלמו מנוכחותה, ואחרים הטיחו בפניה את תלונתם, "את ערבייה!"..והיו שאף הוסיפו, "הכיתה היא ליהודים בלבד". ושירן היתה מאזינה...ונוטשת את המקום" (גיטלמן, 2019:13)

"One of the students reported that Sherine was seen sitting in the computer lab in front of a screen displaying some content in Arabic. Another student said that Sherine came from an Arab village located in the north of the country. Every time Sherine appears in front of the students, they start whispering and laughing. Some of them were just ignoring her presence while some others were throwing accusations at her: "You're Arab!" Others also add: The classroom is only for Jews." Sherine listened and remained silent and she left the place quickly."

In another part of the story, Gettleman describes the Israeli children's culture of fear-of the Arabs. Only hatred and hostility are the themes or concepts that a little child in Israel needs to learn or acquaint with toward the Arab personality in Palestine. Through her character Jay, the author tells how the Israel students try to caution each other about the Arab girl Sherine. She says:

"שירה פגשה את חבריה לכיתה גיא וליאור: "השארת את החברה שלך אצל הערבים?"קרא אליה גיא בחיוך זדוני ובמבט חתרני...שירה התעלמה מדבריהם והמשיכה בדרכה...אז איפה היא?" שאל גיא והאיץ את צעדיו כדי להדביק את קצב הליכתה של שירה. "מי?" "מה מי? איפה שירן?" לא יודעת", השיבה ונעצרה לרגע..."היא בטח בביקור קרובים", פלט ליאור ושניהם צהלו שוב...."רגע, תגידי" פנה גיא אל שירה בדיוק כשהפנתה את גבה אליהם והחלה להתרחק. "את בטח יודעת, את החברה הכי טובה שלה, היא באמת ערביה? השמועות נכונות?"..."כן, כן" אמר ליאור בבוז "אני 
מציע לך להשאיר עין אחת פקוחה הלילה, הערבים האלה ברגע אחד יכולים להתהפך עליך ולהוציא סכין"..."מה אתה רוצה, אני באמת לא מבינה" עכשיו שירה כבר ממש התרגזה "אתה מדבר על מחבלים. יש מחבלים ויש את שאר האנשים בעולם...איך יכול היה גיא לומר על שירן דברים נוראים כמו אלה, הרהרה שירה, מה חשב לעצמו והוא בוודאי לא היחיד, מדוע בני האדם נוהגים כאויבים זה לזה? איזה עולם זה בו אנו חיים, שילדים רבית-ספר מפגינים שנאה לעם אחר ומבטאים זלזול איום וחוסר כבוד כלפי כל אדם באשר הוא." (גיטלמן, 2019: 44-41). "Chirah met her classmates Jay and Lior, and so Jay went to her with a smile and a malicious look. He called her saying: "Did you leave your friend with the Arabs?" Then, Chirah ignored his words and went on her way, so Jay quickly came to catch her asking: "Where is she?" Chirah stopped and asked him back: "Who?" He replied: "What do you mean by who?" "Where is Sherine?" Chirah answered. "I don't know! She might be visiting her relatives." Then Lior got rid of her and both of them returned to Lior and Jay laughing again. Jay turned to Chirah, who then started walking away from them, requesting her to stop: "Just a moment! Tell me Who is your best friend? Is it really Arab? Are the rumours true? Lior replied with contempt: "Yes!" He added: "I suggest that you remain cautious and alert during the night, because it is possible for these Arabs at any moment to turn against you and take out the knife." Chirah began to feel mad and she headed to Lior asking: "What do you want? I really don't understand. You're talking about 'saboteurs'? There are saboteurs but there are other good people in the world."Chirah thought of Jay's words: how Jay could talk about Sherine in such terrible things as what he thinks of himself. He is certainly not the only one! Why do humans act as enemies to each other? What a terrible world we live in, as children in school learn hatred for other peoples and express their mockery and contempt for everyone."

In the extract above, the author describes how largely Lior and Jay feel of fear and anxiety as they see their would-be-classmate Sherine. They consider her as a frightening human being that only needs to revenge, the matter which indicates to the role of the Zionist education in distorting the Arab image (Abu Zureiq, 2000: 81; Shalhat, 1986: 20). In addition, the author represents the Israeli concepts of hatred and hostility toward the Arabs by the demonstrations made by a group of Israelis with racial words and expressions. On the other hand, Gettleman tries to reveal the positive aspects of the Arab personality through her character Sherine as the latter refuses what those Israelis claim or require as they only represent a real obstacle to any peace negotiations between the Arabs and Israel's. She says:

"לפתע קולות אנשים צורחים מהדהדים באוזנה של שירן....מה זה, הפגנה?" חשבה לעצמה והאיצה צעדיה עד שהצליחה לשמוע היטב "מוות לערבים!" מישהו צועק מאחורי המכשיר וחבריו לקבוצה חוזרים בקולם כמו עדר "מוות לערבים", כשהתקרבה קראו עיניה את השלט "אומרים לא לטרור", ובשלט אחר שעליו כתוב בגדול "ערבים לעזה....היא הביטה בהם, ניצבת במרכז מול הבחור עם המגפון, ואז, כהרף עין חטפה אותו מידו, התרחקה צעד אחד אל מול המפגינים ושאגה אל תוך 
The Dual Attitude towards the Arab Personality in the Contemporary Hebrew Children's Literature: A Critical Analysis of Ronette Gettleman's 'On Her Way'

המגפון: "אתם חבורת אידיוטים"..."בגלל אנשים כמוכם אין כאן שלום, לכו למשפחות שלכם

ולשכנים שלכם ותפזרו אהבה, לא שנאה, ואולי תגלו שגם בצד השני יש מי שאוהב אתכם"....ושירן שהפליאה לא רק את המתנגדים האלה, אלא גם את עצמה במעשה שכזה, היא קראה אל תוך המכשיר בקול חזק אך לא בצעקה "זו לא הדרך! פשוט תלכו" היא החזירה את המכשיר לאותו איש

ועובה את המקום"(גיטלמן, 2019: 61-60)

"Sherine suddenly heard voices of people hesitating in her ear. With quick steps, she managed well to hear the phrase "Death to the Arabs!" So, I asked what this is! "Is that a demonstration?" One of the demonstrators screamed from behind the device saying: "Death to the Arabs! His protesting friends return with one voice: "Death to the Arabs!" As she approached the demonstration, she read a sign saying: "Say no to terror" and another sign reading "Arabs to Gaza." Sherine looked at the demonstrators and stood in the middle in front of a young man who held a microphone, and quickly the microphone was taken from him. I took one step back in front of the demonstrators and started chanting and shouting at the microphone saying to them: "You are a group of fools! Do you know why? Because of people like you, there is no peace here! Go to your families, belongings and neighbors and spread love and peace among them. [...] Sherine not only surprised her opponents, but also herself. She called out loudly: "This is not the way! Simply just go." Then she returned the microphone to the same person and left the place.”

\subsection{Culture of Peace Perceived by Israeli Children}

The real and total peace between Israelis and Arabs will never be true unless the land-for-peace formula is effective and the Arabs get their legitimate rights (Abdul-Maqsoud, 2010: 503; Sabri, 1991: 31). This culture of 'peace' has been heavily called to in Israel—and disseminated particularly among young children - for one main purpose: taming the Arab personality. All these calls to 'peace' fall under the Israeli educational umbrella and relevant literary works. Such calls basically aim at deforming the Arab image in the minds of the Israeli children (Rajab, 2004: 11; Suleiman, 2011: 217). According to this strategy, this kind of peace, therefore, has only one meaning: the co-existence between Israelis and Arabs is refused and the hate speech is the one to adopt and follow. Actually, those who call over peace always require the Arabs to recognize the Israel's legal rights in Palestine (Mezal \& Amro, 1989: 108; Cohen, 1988: 16; Sabri, 1999: 154).

The subject short-story reveals how children think of the culture of peace from an Israeli perspective. Going against the idea of co-existence as called to by Miss Iris, any real sort of peace with the Arabs is almost refused (Rasheed 1997: 99). According to the Israeli children now and then, the Arabs are only a never-ending menace to the state of Israel or the living of any Jews on "their" promised land (cf. Elie Podeh cited in Hudeib, 2017: 60). As a matter of fact, the Arab or Palestinian people, as shown by some of the characters in Gettleman's story, namely Jay, Alon and Etan, do not wish to establish real peace with Israelis and that Arabs want to loot their land "the land of Israel". It is then a strong reference 
to the Israeli policies or Zionist ideologies in connection with any settlement of their struggle with the Arabs (Suleiman, 2011: 153). In this respect, the author says:

"המחנכת איריס אמרה מעוניינים בדו קיום ובשלום אם לא בכל העולם אז לפחות בתוכנו, במדינת ישראל. והתלמידים הבוגרים, חלקם דחו את המסרים..."הם לא באמת רוצים שלום אתנו" אמר איתן "נכון" קפץ מכיסאו אלון בהתלהבות מוחצנת "כל מה שהם רוצים זה את האדמה שלנו, הם רוצים את כל המדינה לעצמם." איריס נסתה להת"יח, אך קולות תלמידיה קטעו אותה שוב. "אין הבדל בין ערבי ישראל לערבים שהם לא מישראל ובכלל לא היהודים ולא הערבים מעוניינים בדו קיום," המשיך את דבריו איתן ולא פסק.... "אני חושב שתהליך השלום הוא פשוט בדיחה וטוב יהיה אם ראש הממשלה הנכבד יחזור למקומו בכנסת בירושלים ויעבוד באמת לטובת אזרחי המדינה האמיתיים, התושבים היהודים של מדינת ישראל"...בשעה שהתלמידים המתינו בחדר מדעים למורתם גילה, שוחחו איתן וגל על השיעור של איריס "ממש עצבנה אותי זו," אמר בכעס איתן (גיטלמן, 2019: (22-20)

"Miss Iris said that we are all interested in the concepts of co-existence and peace, if not in the entire world, at least inside our country, the state of "Israel". Some of the mature students refused to listen to these words. Eitan says: "The Arabs do not really want peace with us." Alon leaps from his seat quickly, confirming the words of Eitan: "Yes, that's right." "All the Arabs want is our land! The land of Israel. They want our country as a whole for themselves." Alon adds. Miss Iris came back and tried a brainstorming move, but her students' voices stopped her again. Eitan relentlessly continues shouting: "There is no difference between Israeli Arabs and Arabs outside Israel. Jews and Arabs are not interested in the culture of coexistence. I believe the peace process is a joke! It would be better for the Prime Minister to return to his seat in the Knesset in Jerusalem and really work for the citizens of Israel, only the Jewish citizens. While the students were waiting in the science room for their teacher Jila, Eitan and Gel and a group of students talked about the dialogue in the lesson of Miss Iris. Eitan angrily said: "Really, this teacher drove me mad."

In another part of the story, Gettleman shows via Miss Iris the importance of negotiations or the positive attitude to real and total peace. According to her, this thought can be achieved by changing the hatred and hostility stereotype associated with Arabs, presenting Arabs positively and installing real concepts of peace in the minds of Israeli children through co-existence between Arabs and Israelis. She believes that doing these things positively affects both Israelis and Arabs in Palestine at least. This view is supported by Chirah in her position on the idea of accepting the other, her belief in the culture of peace and her criticism of the Israeli government's unwillingness to proceed with real negotiations leading to peace between the two sides. This shows an important change in the mentality of some Israeli children and their criticism of the peace process from an Israeli perspective. The call to build a new future for both peoples is based on real principles and options for peace. The author says: 
The Dual Attitude towards the Arab Personality in the Contemporary Hebrew Children's Literature: A Critical Analysis of Ronette Gettleman's 'On Her Way'

"המורה איריס ציינה והדגישה גם את חשיבות תהליך השלום על אף מעשה העוולה וכמה חשוב" שכולנו, יהודים וערבים, נלמד להסתדר יחד בארץ ישראל. איריס דיברה גם על ערבי ישראל שסובלים לא פחות מהיהודים מהסכסוך הישראלי-ערבי העתיק", וגם הם "כמוני וכמוכם" היא אמרה, מעוניינים בדו- קיום ובשלום אם לא בכל העולם אז לפחות בתוכנו, במדינת ישראל.... והדיון ממשיך עם מרבית התלמידים בחדר, לבסוף הגיע גם אל שירה, כבר הרימה את קולה "בסך בכל באמת אין פה פרטנר אמיתי לשלום כך שלא יהיה שלום עם הערבים גם לא בעוד מיליון שנה" " (גיטלמן, 2019: 20). "Miss Iris pointed out and also emphasized the importance of the peace process: "Despite the fact of injustice, we must all teach both Jews and Arabs how to live and settle together in the land of Israel." Iris also talked about the Israeli Arabs who suffer as much as the Jews from the old Arab-Israeli conflict. "They are also like me and you," Iris also adds: "We are all interested in the concepts of peace and coexistence, if not that in the entire world, at least inside our country, the state of Israel [...] Finally, it was the turn of Chirah, who then raised her voice: "There is no real partner here for peace; there will be no real peace with the Arabs, even after a million years."

However, her calls for negotiations and peace are not accepted by some of her students. Some of the Israeli children's thought of peace is based on their government's one, and the state of Israel itself does not recognize any legal rights of the Arabs (cf Abdul-Maqsud, 2010: 503-521). In this spirit, the Israeli author, Arael Ovic, in his poetic collection My Peace explains the negative attitude(s) of both Arab and Jewish children toward their world; it is a world of hatred, hostility and destruction in spite of their desires or rights in peace and safety (cf Sabri, 1999: 25-44).

Regarding the coexistence and positive attitude towards the Arab personality, this is embodied in the story through the teacher's 'Sarit' attitude towards Sherine and the teacher's reaction to some Israeli students who refused Sherine's presence in the Isareli school. Their attitude simply changed toward her when they heard and knew that she is Arab. The author says:

"שרית בירכה שירן בברכת בוקר טוב וOימנה לה בידה לשבת.... גברה Oקרנותם של התלמידים... הילדים הביטו זה בזה ואחר בשירן ואז במורה שרית...תלמידים, אני מבקשת שקט!" קראה שרית בקולה הסמכותי והפסיקה כל רחש. כולנו ישראלים," סיכמה. אפילו המורה לא ידעה אם יש ילדה

$$
\text { ערביה בכיתה" (11-9). }
$$

"The teacher, Sarit, greeted Sherine saying "good morning". She pointed to her and asked her to sit on the chair [...] The students' curiosity increased, and they started looking at each other, as well as looking at Sherine and the teacher [.....] So the teacher called the students and stopped their whispers saying, "Dear students, please be calm and silent. We are all Israelis." The teacher did not know that there was an Arab girl in the classroom." 
In another part of the story, the culture of peace and coexistence among students are shown by the headmaster of the school 'Avi Elyaho', who praised Sherine and her sporting talents, although she is an Arab. The author says:

"בשבוע האחרון של שנת הלימודים, טו שירן והוריה לבואנס איירס, בירת ארגנטינה, לקראת השתתפותה של שירן בתחרות האולמפיאדה. עמם במטוס היו גם עשרות Oפורטאים ישראלים...באותה שעה התקיים בבית הספר טקס הסיום של הכיתות י"ב,....אירוע ללא נוכחותה של שירן....על במת הרחבה הגדולה, עלה מנהל בית הספר התיכון, אבי אליהו, ונאם לפני תלמידיו על סיום התקופה ועל תחילתה של דרך אישית לכל תלמיד.... אבל לפתע השתתקו כל התלמידים כאשר שמה של שירן צץ בנאומו של אבי אליהו: "ונאחל לה הצלחה רבה בתחרות. היא מייצגת את כולנו," סיכם המנהל והגאווה ניכרה בקולו. סינן גיא, "מייצגת אולי את עצמה," אמר בלעג לחברו איתן" (63-

"Sherine traveled with her parents in the last week of the school year to Buenos Aires, the capital of Argentina, to participate in the Olympic Games. There were her dozens of Israeli athletes with her [....] During that time, a graduation ceremony for the twelfth grade was held at the school [....] The ceremony held without the girl, Sherine, attending [...] During that time, the high school headmaster Avi Eliyaho went up on the stage of the Grand Theater and spoke to his students about the end of a school stage and the beginning of a new and personal stage for each student [..... Suddenly, all students were silent when Sherine's name was mentioned in Avi Eliyaho's speech. He finished his speech with being proud of Sherine; he said, "We wish Sherine all success in the competition; she represents all of us."

Regarding the Israeli student Chirah's positive attitude towards Sherine, we find that the author also reflects her positive outlook on the Arab character and attempts to instill the concepts of coexistence between Israeli and Arab children. This attitude was embodied by Chirah's reaction to her Israeli friends Lior and Jay when they warned her of Sherine. All Arabs, according to them, are described as "saboteurs" or "terrorists". Chirah expressed her opposition to the generalization which looks at all Arabs as saboteurs. The author says:

"פנה גיא אל שירה, רגע, תגידי, "את בטח יודעת, את החברה הכי טובה שלה ערבייה? השמעות נכונות"? "אתה יודע גיא, אתה צריך להיזהר משמועות," אמרה שירה...."גם על שמעון פרס היו שמועות שאמא שלו ערבייה ובסוף זה התגלה כשקר, ובכלל, גם אם זה נכון, אז מה?"...מה אתה רוצה? אני באמת לא מבינה,"....אתה מדבר על מחבלים. יש מחבלים ויש אנשים רגילים בעולם. חוץ מזה, אני לא אתן לך לדבר ככה על שירן. שירן תלמידה נהדרת....היא חברה נפלאה, מה יש לך נגדה? היא עשתה לך משהו רע? "לא, אבל..."היא החל לגמגם ושירה לא אפשרה לו לדבר כלל, "אז תפסיק! שירן היא החברה הכי טובה שלי, ואני לא מוכנה שאתה או אף אחד אחר ידבר עליה ככה" 
The Dual Attitude towards the Arab Personality in the Contemporary Hebrew Children's Literature: A Critical Analysis of Ronette Gettleman's 'On Her Way'

"Jay directed to Chirah saying: "Tell me! Is your best friend an Arab?" Are the rumors about that true?"Chirah replied, "Did you know Jay that you should be careful about the rumors?" She added "Even on Shimon Peres, there were rumors that his mother was an Arab, and at the end it turned out to be false rumors, and even if it were true, what then? [....] What do you want? I really do not understand [...] You are talking about 'saboteurs'. There are 'saboteurs'; there are ordinary people in the world. Otherwise, I will not allow you to speak negatively about Sherine. She is a wonderful student [.....] She is also a wonderful friend. What do you have against her? Did she do something bad to you?" Jay stutterly replied, "No, but"[.....] at that time, Chirah did not allow him to speak at all, and she interrupted him "Stop, that's enough! Sherine is one of my best friends, and I will not allow you or anyone else to talk about her in this way."

\section{Conclusion}

On the basis of the critical analysis above, the present study confirms that the CHCL has affected the Jewish children's view(s) toward the Arab personality. Their feelings of hatred, racism and hostility have been strengthened by depicting the Arabs as barbarians or murderers who only seek to exterminate the Jews. This biased, prejudiced and discriminatory thought in literature in general and the short-story genre in particular have been deforming the Arab image, even if some few authors stand on the opposite side. In actual fact, the culture of peace or any sort of co-existence on such a historic place as Palestine would be impeded as long as those feelings or concepts used to be deepened in the minds of the Israeli children. Eventually, this study concludes that:

- The persons of thought and education in Israel have a big role in strengthening the concepts of hatred and hostility in the minds of children and, hence, deforming the Arab image in literature. They respect no moral or human values in dealing with their Arab "countrymen" and are only seeking to spread aggressive feelings among school students in Israel. That's also what the decision-makers in the Arab world need to educationally consider and try hard to confront.

- The author could demonstrate some of the Israeli students' hostile view toward the Arab girl in the story by her characters, Lior, Eitan and Jay, who refuse her to be a student of their school. The story is actually full of phrases and expressions that toughen the children's feelings of hatred or, more precisely, fear once they hear the word 'Arab'. However, the negative image depicted for the Arab person in this story is almost because of the Zionist educational ideologies.

- The study has shown that the author, Gettleman, is successful in her attempts to highlight the positive image of the Arab personality that Sherine represents. According to Gettleman, Sherine is ready to be amalgamated with the Israeli society through establishing friendly relations with some of her Israeli friends in the Israeli school, especially Omir, Eidin and Chirah and joining a sports club in the city of Haifa to achieve her dream of being a famous athlete and win the gymnastics competition in the Olympic championship. Sherine's readiness can be taken as an indication that Sherine represents the Arab personality that calls for a culture of coexistence and real, fair peace. Sherine shows openly her refusal of the anti-Arab demonstrators and the author tries to highlight the positive aspects of the 
Arab personality who refuses what those Israelis claim or require as they only represent a real obstacle to any peace negotiations between Arabs and Isralelis.

- The study has also shown that the author Gettleman calls for instilling a culture of peace and coexistence between the Arabs and Israelis. This story reflects the dual attitudes of some of the Israeli children towards Arabs. The author expresss some trends of hatred and hostility in the conscience of some Israeli children towards the Arab personality and their calls for rejecting any negotiations of peace with Palestinians. On the other hand, the author highlights some attitudes of coexistence among some Israeli children that oppose anti-Arabs and racism, and instead urge Israeli children to coexist with Arabs. This was represented in the story by the teacher Iris and her opinion of the Palestinian-Israeli conflict. She talks to children in the school about the importance of peace and coexistence between Israelis and Arabs. Likewise, Chirah shows positvive attitude towards her Arab friend, Sherine, through defending her in front of some Israeli students, Jay, Lior, Alon, Eitan, expressing her view regarding the peace process and her criticism of the role and retreat of the Israeli government in proceeding with the negotiations process. Similarly, Avi Eliyaho praises Sherine and expresses his pride of her. He also points out that sherine represents all israelis in the Olympic Games. From this standpoint, it can be said that this story represents a new orientation in contemporary Hebrew children's literature towards the Arab character. The story shows a positive view of the Arab image as it expresses the will of at least some of the representatives of the two peoples towards a culture of coexistence. Although they are few, they constitute a new generation and a new view regarding co-existence and peace.

To end with, the image of an Arab person as depicted in the children-oriented literature in Hebrew has somehow changed. On the one hand, even after the peace treaty(s) in the region, the image of an Arab is still being deformed and misrepresented with a lot of hatred and hostility in the minds of some children. That's what the educational ideologies in Israel go for in connection with the culture of peace. Gettleman's characters-Jay, Alon, Lior and Eitan-represent the Israeli children's refusal of any pursuits for peace with the Arabs. On the other hand, the author tries to be fair somewhere in her story or, at least, neutral to the issue of the Arabs in Palestine describing how they are also suffering from the Arab-Israeli struggle. Some of the author's characters, Miss Iris, Sarit, Chirah and Avi Elyaho call to a culture of peace by avoiding any total or final judgments on the Arab people. However, this individual call to the same — as per which the Arab legal/legitimate rights will be definitely recognized —is almost impossible if the common thought of racism, hostility and hatred in the CHCL continues. To attenuate these negative thoughts and feelings towards Arabs, there should be trends to get rid of culture of hatred and hostility towards Arabs in the minds of Israeli children. This can be achieved through presenting Arabs positively in Hebrew children's literature. Doing so helps to enhance the culture of co-existence among Arabs and Israelis as neighbours who live peacefully side by side. 
The Dual Attitude towards the Arab Personality in the Contemporary Hebrew Children's Literature: A Critical Analysis of Ronette Gettleman's 'On Her Way'

$$
\begin{aligned}
& \text { الموقف المزدوج تجاه الشخصية العربية في أدب لأطفال العبري المعاصر: } \\
& \text { دراسة تحليلية نقدية لقصة (في طريقها ) لرونيت جيتلمان } \\
& \text { محمد النصيرات، محمود العمرات، تيسير العزام }
\end{aligned}
$$

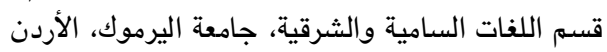

$$
\begin{aligned}
& \text { الملخص }
\end{aligned}
$$

حظيتٌ الأديبة "رونيت جيتلمان" بمكانة متميزةٍ في أدب الأطفال العبري المعاصر، باعتبارها من أشهر الأدباء الذين تناولوا خطاب الكراهية وثقافة السلام في أدب الأطفال العبري، إذ يصنف خطاب الكراهية تحت عنوان "الأدب الصهيوني". وتمثل ذلك من خلال دراسة قصة (في طريقها) (دדרכה) أنموذجاً، للكاتبة "جيتلمان"، التي تُعد من أبرز الأعمال النثرية التي تناولت صورة العربي ومكانته في عقلية الطفل الإسرائيلي. من هنا، وقع الاختيار على قصة (في طريقها)، في محاولة للتعرف، من خلال نماذج مختارة من هذه القصة، إلى كيفية تصوير الإنسان العربي تصويراً سلبياً، وتوضيح مكانته في أدب الاطفال العبري. فعبرت الكاتبة على لسان بعض الأطفال الإسرائيليين عن ترسيخ مفاهيم العداء والكراهية في وجدانهم تجاه الثخصية العربية. إذ أن الصورة التي رسمتها الكاتبة في أذهان بعض الأطفال كغيرها من الأدباء الإسرائيليين، تُثير الخوف والقلق والرعب في نفوسهم لمجرد سماعهمم كلمة "عربي". وتجعل أيضا من ثقافة الكراهية والعداء عنواناً للطفل الإسرائيلي. وفي المقابل أبرزت الكاتبة جانبا من ملامح ثقافة التعايش والسلام لدى بعض الأطفال الإسرائيليين تجاه الثخصية العربية. فجاءت هذه القصة بما تحويه من مضامين لتؤكد ازدواجية الثخصية الإسرائيلية فيما يتعلق بوجهة نظرها تجاه الثخصية

العربية. ويعد هذا بمثابة توجه جديد في أدب الاطفال العبري المعاصر تجاه الثخصية العربية والنظرة إليها نظرة إيجابية. الكلمات المفتاحية: أدب الأطفال العبري المعاصر، "في طريقها"، خطاب الكراهية، ثقافة السلام، رونيت جيتلمان. 


\section{Endnotes}

${ }^{1}$ Uri Avnery (1923-2018) was an Israeli writer, politician, and founder of the Gush Shalom peace movement. A member of the Irgun as a teenager, Avnery sat for two terms in the Knesset from 1965 to 1974 and from 1979 to 1981 . He was also the owner of the news magazine HaOlam HaZeh from 1950 until its closure in 1993. Avnery was the author of several books about the Israeli-Palestinian conflict, including 1948: A Soldier's Tale, the Bloody Road to Jerusalem (2008); Israel's Vicious Circle (2008); and My Friend, the Enemy (1986).

${ }^{2}$ Geulah Cohen (1925-2019) was an Israeli politician and activist who founded the Tehiya party. She won the Israel Prize in 2003. Between 1974 and 1992, she served as a member of Knesset, initially for Likud. She changed her political affiliation to Tehiya in 1979. In 1992, she lost her seat in the Knesset.

${ }^{3}$ For further information on the status and trends of the educational thought in Israel, see Abdul Maqsoud, 2010: 22-31.

${ }^{4}$ Also named as Who Stole the Moon.

${ }^{5}$ All the excerpts in this study which are taken from On Her Way are translated by the researcher.

\section{References}

Abdul-Aal, Safaa. 2005. Racial Education in the Israeli Curricula. Cairo, Egypt: Egyptian Lebanese Library.

Abdul Maqsoud, Mohammad. 2010. Trends of Contemporary Educational Thought in Israel: Challenges and ways of confront. Cairo.

Abu Ghadeer, Mohammad. (2008). Israeli Personality in Globalism and Privatism: Local and Regional Reflections. In Cairo University's Literary and Language Studies 37.

Abu-Zuraiq, Foad. 2000. Zionist Literature and Public Propaganda. Damascus, Syria: Arab Writers' Union.

Al-Hudaib, Faiza. 2017. Zionist Thought and Hebrew Writings. Amman, Jordan: Zahran Publication and Distribution.

Avnery, Uri. 1981. Arabs in Geula Cohen's writings from Avnery's point of view, Haolam Hazeh Magazine: 2283.

Cohen, Adir. 1985. An ugly face in the mirror: A reflection of the Jewish-Arab conflict in Hebrew children's literature. Tel aviv, Reshafim.

Cohen, Adeir. 1988. An Ugly Face in the Mirror: Reflections of the Arab-Jewish Struggle on Children's Literature. Trans. Ghazi Sa’adi. Amman: Al Jaleel Palestinian Research Centre.

Cohen-Almagor, Raphael. 2011. Fighting hate and bigotry on the Internet. Policy \& Internet 3 (3): 1-26.

Dar, Yael. 2017. Hebrew children's literature: Introduction. Tel -Aviv University.

Faris, Robert, Amar Ashar, Urs Gasser and Daisy Joo. 2016. Understanding harmful speech online. Berkman Klein Center Research Publication No. 2016-21. Available at: https://papers.ssrn.com/sol3/papers.cfm?abstract_id=2882824. 
The Dual Attitude towards the Arab Personality in the Contemporary Hebrew Children's Literature: A Critical Analysis of Ronette Gettleman's 'On Her Way'

Gettleman, Ronette. 2014. Delicious ripe orange. Zmora Publishing House Books, Israel.

Gettleman, Ronette. 2016. The wonderful journey of Bone the bear. Zameret Publishing House Books, Israel.

Gettleman, Ronette. 2019. On her way. Matar Publishing House Books, Israel.

Gettleman, Ronette. 2014. How to identify handwritten distress signs. Mako website.https://www.mako.co.il/spirituality-newage/more/Article-44f19dc16688841006 distress.htm

Halkin, Simon. 1960. Introduction to modern Hebrew fiction. The Replication Factory, Jerusalem.

Jubah, Abdel Khaliq. 2005. Israeli-Zionist Issues in the Modern Hebrew Literature. In Cairo University's Literary and Language Studies Series 16.

Keret, Etgar. 1992. Pipelines 'Tzinorot' Am Oved Publishing House Books, Israel.

Lutzsschwily, Lisa. 2019. New book for Ronette Gettleman from Rehovot: On her way. News site Zero Eight. https://www.news08.net/

Messiah, Selena. 2006. Imagine an enemy, political rivals in the children's and youth before and after the 1948 war. The Open University of Israel.

Mezal, Ghanim. 1986. The Arab Personality in the Modern Hebrew Literature. Amman: Al Jaleel Palestinian Research Centre.

Mezal, Ghanim and Younis, Amro. 1989. The Arabs in the Hebrew Children's Literature. Al Khalil University: Research Centre.

Morag, Gilad. 1987. Love and shoot the Arab face in the Hebrew literature. Mazenim, Aliterary Journal 5: 17-25.

Qarnia, Mohammad. 2011. Racial Bias in the Zionist Literature. Damascus, Syria: Arab Writers' Union.

Rasheed, Haroon. 1997. Zionism in the Israeli School Textbooks. Saudi Arabia: Ministry of Education's Book of Knowledge.

Rajab, Mustafa. 2004. Children's Literature: Realities and Prospects. Cairo, Egypt: Cognitive Studies Centre.

Regev, Menahem. 1983. A short guide to children's literature. Tel-Aviv.

Regev, Menahem. 1992. Children's literature reflections: Society, ideology and values in Israeli children's literature. Ophir Publishing, Tel Aviv.

Ronette Gettleman: On her life history. The Nuritha Books and Literature website. https://simania.co.il/bookdetails.php?item_id=981951

Ronette Gettleman: Delicious ripe orange. The Simania Books and Literature website. https://simania.co.il/bookdetails.php?item_id=981951

Ronette Gettleman: The wonderful journey of Bone the bear. The Simania Books and Literature website. https://simania.co.il/bookdetails.php?item_id=981951

Ronette Gettleman: On her life history. Hebrew website. https://simania.co.il/ bookdetails.php?item_id=981951 
Ronette Gettleman: On her life history. The Steimatzky Books website. https://simania.co.il/bookdetails.php?item_id=981951

Rosenthal, Eti. 2005. The values embodied in preschool children's literature in state education: Children's and youth literature (Philosophiae Doctor of Education). Bar-Ilan University.

Rudin, Shai. 2012. Violence: On the theme of violence in modern Hebrew literature. Resling Publishing House Books, Tel Aviv-Yafo (Israel) -place of publication.

Rudin, Shai. 2015. Portrayal of the Arab in Israeli for children and youth 1985-2015. Journal of Children and Youth Literature 'Sifrut Yeladim Vanoar' 138: 30-45.

Sabri, Sana. 1992. Ideological Trends in the Contemporary Hebrew Children's Literature in Israel. Unpublished Doctoral Thesis, Ain Shams University, Cairo.

Sabri, Sana. 1995. Jewish-Arab Relations in the Hebrew Children's Literature in Israel. Ibda'a Journal 3.

Sabri, Sana. 1997. How Jews See Their Children. Amman, Jordan: Al Eman Publishers and Distributors.

Sabri, Sana. 1999. Culture of Peace for Israeli Children: An Analysis of Diwan 'My Peace and Safety'. $2^{\text {nd }}$ Ed. Cairo: Madbouli Library.

Samida, Mahmoud. 1984. Arab Palestinian Personality in the Israeli Short Story. Unpublished Doctoral Thesis. Ain Shams University, Cairo.

Samida, Mahmoud. 1988. Zionist Literary Strategy in Terrifying the Arabs. Abu Dhabi: Al Ettihad Press and Publications.

Samida, Mahmoud. 2000. Palestinian Personality in the Hebrew Short Story. Cairo University's Journal of Literary and Language Studies 8.

Siegel, Alexandra. 2019. Online hate speech. In social media and democracy: The state of the field. Stanford, CA. Geraadpleegd van https://alexandra-siegel.com/wpcontent/uploads/2018/09/ Siegel_Online_Hate_Speech.pdf

Shalabi, Asma. 1992. Political Education in the Children's Literature: A Comparative Study of Egypt and Israel. Unpublished Master's Thesis, Ain Shams University, Cairo.

Shalhat, Antwan. 1986. The Arab Personality in the Hebrew Literature. Amman, Jordan: Ibn Rushd Publishers and Distributors.

Shavit. Zohar. 1996. Just childhood: Introduction of poetics of children's literature. The Open University of Israel, Tel Aviv.

Shavit, Zohar. 2002. Hebrew children's literature: 'Olam Ktan' of Children's and Youth Literature 1: 1530.

Suleiman, Ali. 2011. Violence in the Zionist Literature. Damascus, Syria: Syrian General Book Authority. Snir, Peleg. 2016. Snir Peleg's book world. The Van Leer Jerusalem Institute. https:/www.news08.net/ Weinbach, Liora and Lauden Edna. 1988. Dictionary of Hebrew Language Studies. Ad Publishing, Tel Aviv.

Weidmann, Nils B. 2009. Geography as motivation and opportunity: Group concentration and ethnic conflict. Journal of Conflict Resolution 53 (4): 526-543. 
The Dual Attitude towards the Arab Personality in the Contemporary Hebrew Children's Literature: A Critical Analysis of Ronette Gettleman's 'On Her Way'

Zinberg, Israel. 1978. A History of Jewish Literature: Haskalah at its zenith. Ktav Publishing House, New York. 